\title{
Genetic diversity and phylogenetic relationship analyzed by microsatellite markers in eight Indonesian local duck populations
}

\author{
Dwi Nur Happy Hariyono ${ }^{1}$, Dyah Maharani ${ }^{1, *}$, Sunghyun $\mathrm{Cho}^{2}$, Prabuddha Manjula, \\ Dongwon $\mathrm{Seo}^{2}$, Nuri Choi ${ }^{2}$, Jafendi Hasoloan Purba Sidadolog ${ }^{1}$, and Jun-Heon Lee ${ }^{2}$
}

\begin{abstract}
* Corresponding Author: Dyah Maharani Tel: +62-274-513363, Fax: +62-274-521578, E-mail: d.maharani@ugm.ac.id
\end{abstract}

${ }^{1}$ Department of Animal Breeding and Reproduction, Faculty of Animal Science, Universitas Gadjah Mada Yogyakarta 55281, Indonesia

2 Division of Animal and Dairy Science, College of Agriculture and Life Sciences, Chungnam National University, Daejeon 34134, Korea

ORCID

Dwi Nur Happy Hariyono

https://orcid.org/0000-0002-3136-1592

Dyah Maharani

https://orcid.org/0000-0003-2446-462X

Submitted Jan 17, 2018; Revised Apr 13, 2018; Accepted May 22, 2018
Objective: At least eight local duck breeds have been recognized and documented as national germplasm of Indonesia so far. It is necessary to genetically characterize the local duck breeds for aiding conservation and future improvement strategies. Thus, this study was carried out to assess genetic diversity and phylogenetic relationship of eight local duck populations of Indonesia using microsatellite markers.

Methods: In total, 240 individuals (30 individuals each population) from Alabio (AL), Bayang (BY), Magelang (MG), Mojosari (MJ), Pegagan (PG), Pitalah (PT), Rambon (RM), and Turi (TR) duck populations were genotyped using 22 microsatellite markers.

Results: The results showed a moderate level of genetic diversity among populations, with a total of 153 alleles detected over all loci and populations, ranging from 3 to 22 alleles per locus. Observed $(\mathrm{Ho})$ and expected heterozygosity $(\mathrm{He})$, as well as polymorphism information content over all loci and populations were $0.440,0.566$, and 0.513 , respectively. Heterozygote deficiency in the overall populations $\left(F_{\mathrm{IT}}=0.237\right)$, was partly due to the heterozygote deficiency within populations $\left(F_{\mathrm{IS}}=0.114\right)$ and moderate level of genetic differentiation among populations $\left(F_{\mathrm{ST}}=0.137\right)$. The most diverse population was MG $(\mathrm{He}=0.545)$ and the least diverse population was $\mathrm{AL}(\mathrm{He}=0.368)$. The majority of populations were relatively in heterozygote deficiency (except AL), due to inbreeding. The genetic distances, phylogenetic trees, and principal coordinates analysis concluded that the populations can be grouped into two major clusters, resulting $\mathrm{AL}, \mathrm{MG}$, and $\mathrm{MJ}$ in one cluster separated from the remaining populations.

Conclusion: The present study revealed a considerable genetic diversity of studied populations and thus, proper management strategies should be applied to preserve genetic diversity and prevent loss of alleles.

Keywords: Genetic Diversity; Indonesian Local Ducks; Microsatellite Markers; Phylogenetic Relationship

\section{INTRODUCTION}

Attention and awareness to genetic conservation of locally developed livestock breeds have increased in recent years, evidenced by many studies concerning genetic diversity of the breeds. Conservation of genetic diversity plays an important role in sustaining the livestock breeds. Genetic diversity within a species similarly increases the probability of survival in a range of environments [1] and provides genetic materials for future breeding programmes as well as important materials from a scientific point of view. Reducing the genetic diversity of a species means losing not only genetic 'wealth', but also reducing the possibility of the species to adapt to harsh environmental conditions and disease outbreaks [2].

In Indonesia, a number of local duck breeds, namely Alabio (AL), Bayang (BY), Magelang 
(MG), Mojosari (MJ), Pegagan (PG), Pitalah (PT), Rambon (RM), and Turi (TR) were included as important assets by the Indonesian Ministry of Agriculture, and play an important role in a socio-economic aspect as they provide livelihood to smallholders as well as food for humans. Ducks are reared by breeders for egg production and the culled ducks used for meat production. These local ducks are known for their high fitness levels under harsh conditions and ability to survive with coarse and alternative fodder. Because of these important roles, to evaluating and monitoring the genetic diversity status and phylogenetic relationship of these local breeds is highly recommended. Comprehensive knowledge of the existing genetic variability is the first step for the conservation and utilization of domestic animal biodiversity [3,4]. Conservation of local duck breeds should rely upon several sources of information, including the degree of endangerment, adaptation to a specific environment, traits of economic importance, and cultural or historical value of the breeds [5], molecular characterization may provide as an important initial guide.

Recent advances in molecular technology allow us to assess genetic diversity of livestock breeds at DNA level. Microsatellites or simple sequence repeats are recently the most favoured molecular markers for population analysis, owing to the high variability, ease, and accuracy of assaying microsatellites [6]. They may prove particularly valuable for population discrimination and genotype identification [7] due to the high level of polymorphism compared with conventional allozyme markers $[8,9]$. So far, employing microsatellite markers to assess ducks genetic diversity has been established by many studies [10-13] and the reported results provided clear evidence of the usefulness of microsatellites for genetic diversity studies. Using microsatellites in our samples of Indonesian local duck pop- ulations also allow comparison with published studies of local duck breeds from other countries.

In Indonesia, the use of molecular markers for assessing genetic diversity in several local duck breeds has been previously reported, including AL using 7 microsatellites [14], BY using 2 microsatellites [15] and MG using single nucleotide polymorphism (SNP) [16]. In the current study, we attempt to use 22 microsatellite markers in determining the genetic diversity and phylogenetic relationship of eight local duck populations of Indonesia. The results may prove to be valuable for the future breeding programs and conservation of the local duck breeds.

\section{MATERIALS AND METHODS}

\section{Sample collection and DNA extraction}

In total, 240 animals representing eight local duck populations in Indonesia (30 animals per population) were sampled from six provinces (Figure 1). The eight duck populations were AL and MJ from Pelaihari, South Kalimantan; BY and PT from West Sumatera, MG from Central Java; PG from South Sumatera; RM from West Java; and TR from Special Region of Yogyakarta (DIY). The blood samples were obtained from the ulnar vein using vacutainer tubes with K2-ethylenediaminetetraacetic acid anticoagulant. Genomic DNA was extracted from these blood samples using gSYNC DNA Extraction Kit (Geneaid, New Taipei City, Taiwan) following the manufacturer's instructions and stored at $-20^{\circ} \mathrm{C}$ before doing polymerase chain reaction (PCR) amplification. Extracted DNA samples were checked for quality and concentration by electrophoresis on $1 \%$ agarose gel, as well as by a spectrophotometer using the NanoDrop 2000C (Thermo Scientific, Waltham, MA, USA).

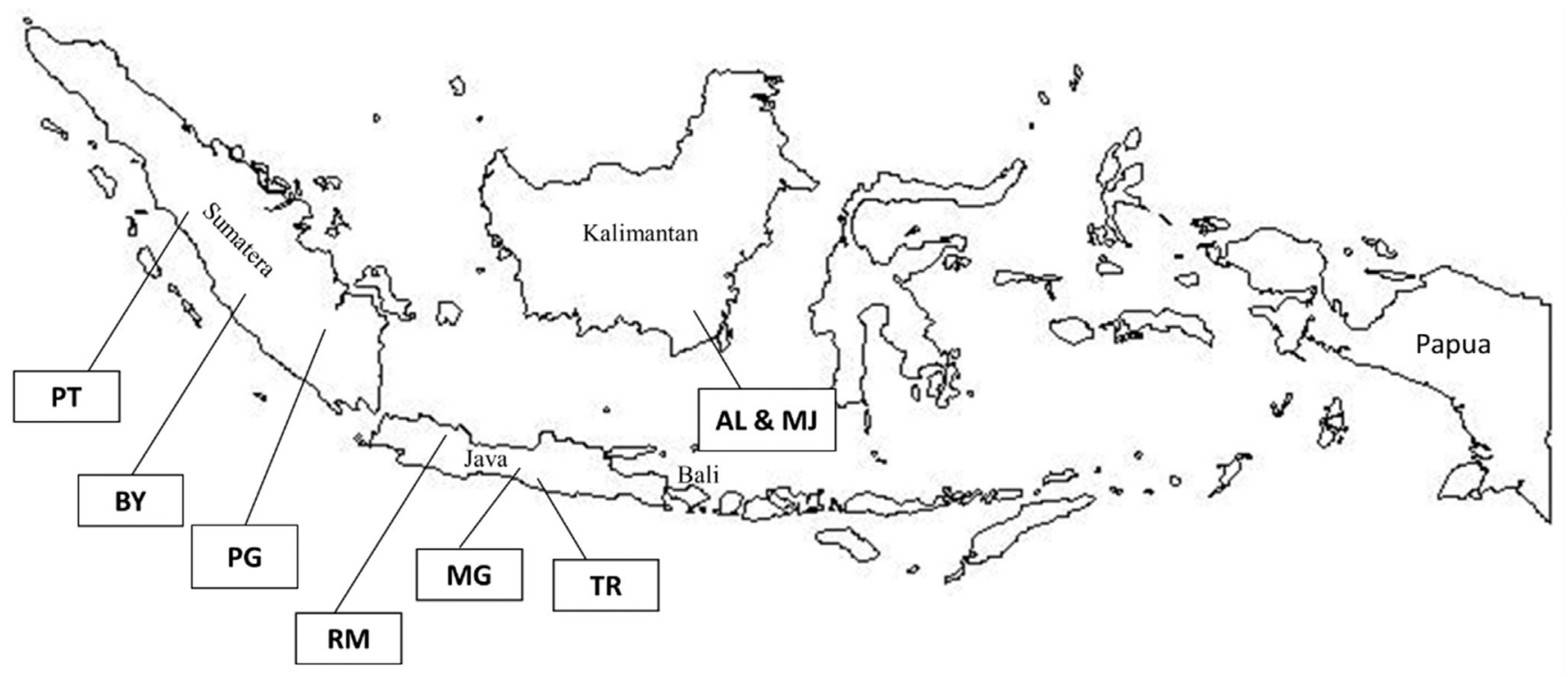

Figure 1. Locations of analyzed eight local duck populations in Indonesia (AL, Alabio; BY, Bayang; MG, Magelang; MJ, Mojosari; PG, Pegagan; PT, Pitalah; RM, Rambon; TR, Turi). 


\section{Microsatellites amplification and genotyping}

Twenty-two microsatellite markers distributed in 6 linkage groups and chromosomes (Table 1) were chosen based on their genomic location and their degree of polymorphism. Primer forward from each pair was modified using capillary-based dye (FAM, VIC, NED, and PET). The PCR was performed in a $20 \mu \mathrm{L}$ volume containing $2 \mu \mathrm{L}$ of $10 \mathrm{ng} / \mu \mathrm{L}$ of duck genomic DNA, $2 \times$ multi HS Prime Taq Premix (GeNet Bio, Daejeon, Korea), 8 pmol of each forward and reverse primer (Applied Biosystems, Foster City, CA, USA), and distilled water. PCR was carried out under following conditions: initial denaturation for $10 \mathrm{~min}$ at $95^{\circ} \mathrm{C}$, followed by 38 cycles of $30 \mathrm{~s}$ of denaturation at $95^{\circ} \mathrm{C}, 30 \mathrm{~s}$ of annealing at $60^{\circ} \mathrm{C}, 30 \mathrm{~s}$ of extension at $72^{\circ} \mathrm{C}$, and final extension for $10 \mathrm{~min}$ at $72^{\circ} \mathrm{C}$ using BIO-RAD T100 Thermal Cycler. The amplified DNA was then genotyped using Genetic Analyzer 3730xl (Applied Biosystems, USA), with genotyping reaction containing $1 \mu \mathrm{L}$ of diluted PCR products, $10 \mu \mathrm{L}$ of Hi-Di Formamide (Applied Biosystems, USA), and $0.1 \mu \mathrm{L}$ of GeneScan-500 LIZ size standard marker (Applied Biosystems, USA). The GeneMapper ver.3.7 (Applied Biosystems, USA) was used for genotype identification.

\section{Statistical analysis}

The genetic diversity among populations was determined by these indicators: number of alleles $(\mathrm{Na})$, observed heterozygosity (Ho), expected heterozygosity (He), and polymorphism information content (PIC) which were estimated using Cervus ver.3.0 program [17], and $F$-statistics, including inbreeding coefficient of an individual relative to the subpopulations $\left(F_{\mathrm{IS}}\right)$, inbreeding coefficient of an individual relative to the total population $\left(F_{\mathrm{IT}}\right)$, and genetic differentiation index between population $\left(F_{\mathrm{ST}}\right)$ which were calculated using GenAlex ver. 6.501 [18]. The software was also employed to determine genetic diversity within each population ( $\mathrm{Na}, \mathrm{Ho}, \mathrm{He}$, and $\left.F_{\mathrm{IS}}\right)$. For phylogenetic relationship analysis, GenAlex software was used to perform pairwise population matrices based on either $F_{\mathrm{ST}}$ or Nei's genetic distance and to construct principal coordinates analysis (PcoA). The resulted pairwise population matrices were then used to construct phylogenetic trees using MEGA software ver. 7.0.14 [19].

\section{RESULTS}

\section{Genetic diversity and differentiation analysis}

Genetic diversity indicators are summarized in Table 1 and Table 2 for among and within duck populations studied, respectively. In total, 153 alleles were detected at these 22 loci in 240 indi-

Table 1. Genetic diversity analysis over all 22 loci and populations based on number of alleles (Na), observed (Ho) and expected heterozygosity (He), polymorphism information content $(\mathrm{PIC})$, and $F$-statistics $\left(F_{1 T}, F_{15,}\right.$ and $\left.F_{\mathrm{ST}}\right)$

\begin{tabular}{llccccccccc}
\hline No. & Locus & Chro. No./Linkage group & $\mathbf{N a}$ & $\mathbf{N}$ & Ho & He & PIC & $\boldsymbol{F}_{\text {IT }}$ & \multicolumn{1}{c}{$\boldsymbol{F}_{\text {IS }}$} & $\boldsymbol{F}_{\text {ST }}$ \\
\hline 1 & AMU13 & - & 4 & 234 & 0.581 & 0.653 & 0.579 & 0.108 & 0.017 & 0.093 \\
2 & APH04 & CAU6 & 7 & 234 & 0.256 & 0.553 & 0.475 & 0.538 & 0.427 & 0.195 \\
3 & APH20 & 8 & 4 & 234 & 0.274 & 0.590 & 0.509 & 0.536 & 0.470 & 0.125 \\
4 & APH24 & CAU3 & 5 & 234 & 0.026 & 0.079 & 0.077 & 0.676 & 0.659 & 0.051 \\
5 & CAUD011 & - & 5 & 234 & 0.470 & 0.590 & 0.505 & 0.196 & 0.091 & 0.116 \\
6 & CAUD031 & CAU1 & 7 & 234 & 0.427 & 0.479 & 0.449 & 0.102 & 0.043 & 0.061 \\
7 & CAUD035 & CAU6 & 6 & 234 & 0.410 & 0.605 & 0.568 & 0.322 & 0.224 & 0.127 \\
8 & CAUD039 & 1 & 6 & 234 & 0.645 & 0.713 & 0.664 & 0.093 & -0.001 & 0.093 \\
9 & CAUD111 & 5 & 6 & 234 & 0.333 & 0.633 & 0.592 & 0.472 & 0.389 & 0.135 \\
10 & CAUD128 & CAU17 & 3 & 234 & 0.496 & 0.503 & 0.380 & 0.010 & -0.068 & 0.072 \\
11 & CAUD040 & CAU12 & 21 & 236 & 0.860 & 0.927 & 0.920 & 0.070 & 0.001 & 0.069 \\
12 & CAUD066 & 1 & 6 & 236 & 0.585 & 0.633 & 0.560 & 0.072 & -0.035 & 0.103 \\
13 & AMU123 & - & 3 & 236 & 0.496 & 0.582 & 0.491 & 0.146 & 0.052 & 0.099 \\
14 & AMU52 & 10 & 6 & 236 & 0.254 & 0.551 & 0.492 & 0.536 & -0.038 & 0.553 \\
15 & AMU68 & CAU9 & 6 & 236 & 0.178 & 0.193 & 0.186 & 0.077 & 0.024 & 0.055 \\
16 & APH08 & CAU6 & 8 & 236 & 0.436 & 0.743 & 0.700 & 0.412 & 0.024 & 0.398 \\
17 & CAUD005 & CAU1 & 9 & 236 & 0.534 & 0.602 & 0.565 & 0.109 & 0.009 & 0.102 \\
18 & CAUD009 & - & 3 & 236 & 0.305 & 0.446 & 0.398 & 0.314 & 0.216 & 0.125 \\
19 & CAUD044 & 10 & 5 & 236 & 0.411 & 0.440 & 0.377 & 0.066 & -0.060 & 0.119 \\
20 & CAUD086 & CAU1 & 6 & 236 & 0.360 & 0.371 & 0.332 & 0.024 & -0.099 & 0.112 \\
21 & CAUD132 & 27 & 5 & 236 & 0.466 & 0.646 & 0.569 & 0.278 & 0.157 & 0.143 \\
22 & CAUD048 & 11 & 22 & 238 & 0.866 & 0.916 & 0.908 & 0.053 & -0.003 & 0.056 \\
& Total & & 153 & & & & & & & \\
& Average & & 6.955 & & 0.440 & 0.566 & 0.513 & 0.237 & 0.114 & 0.137 \\
\hline
\end{tabular}

$\mathrm{N}$, number of individuals; $F_{\mathrm{IT}}$ global heterozygote deficit among eight duck populations; $F_{\mathrm{IS}}$, heterozygote deficit within duck populations; $F_{\mathrm{ST}}$, fixation index as genetic differentiation. 
Table 2. Genetic diversity analysis within duck populations

\begin{tabular}{lccccc}
\hline Population & $\mathbf{N}$ & $\mathrm{Na}$ & Ho & He & $\boldsymbol{F}_{\text {IS }}$ \\
\hline AL & 30 & 3.136 & 0.371 & 0.368 & -0.011 \\
BY & 29 & 4.364 & 0.451 & 0.498 & 0.113 \\
MG & 30 & 4.682 & 0.450 & 0.545 & 0.152 \\
MJ & 28 & 3.818 & 0.464 & 0.486 & 0.037 \\
PG & 29 & 4.545 & 0.441 & 0.485 & 0.111 \\
PT & 30 & 4.227 & 0.396 & 0.443 & 0.084 \\
RM & 30 & 4.864 & 0.458 & 0.535 & 0.171 \\
TR & 30 & 4.864 & 0.488 & 0.519 & 0.077 \\
Average & 29.398 & 4.313 & 0.440 & 0.485 & 0.092 \\
\hline
\end{tabular}

$\mathrm{N}$, number of individuals analyzed; $\mathrm{Na}$, number of alleles; Ho, observed heterozygosity; $\mathrm{He}$, expected heterozygosity; $F_{15}$, heterozygote deficit within duck populations; AL, Alabio; BY, Bayang; MG, Magelang; MJ, Mojosari; PG, Pegagan; PT, Pitalah; RM, Rambon; TR, Turi.

viduals, with the number of alleles per locus ranging from 3 (CAUD128, AMU123, and CAUD009) to 22 (CAUD048), with an average value of 6.96 alleles per locus. Observed and expected heterozygosity values ranged from 0.026 to 0.866 and 0.079 to 0.927 , respectively. The mean expected heterozygosity of 0.566 indicated medium to high levels of genetic diversity in duck populations studied. The PIC value for the loci ranged from 0.07 to 0.920 , with an average of 0.513 .

$F$-statistics were estimated in a fixation index as genetic differentiation $\left(F_{\mathrm{ST}}\right)$, global deficit among eight duck populations $\left(F_{\mathrm{IT}}\right)$, and the heterozygote deficit within duck populations $\left(F_{\mathrm{IS}}\right)$, with an average value of $0.137,0.237$, and 0.114 , respectively (Table 1). The average value of $F_{\mathrm{ST}}$ indicated that about $13.70 \%$ of total genetic variation corresponded to differences between populations, while $86.30 \%$ was explained by differences between individuals.

Generally, within each population, relatively low to moderate genetic diversity was observed, depicted by range values of $\mathrm{Na}, \mathrm{Ho}$, and $\mathrm{He}$ of 3.136 to $4.864,0.371$ to 0.488 , and 0.368 to 0.545 , respectively. All of the duck populations, except AL, showed a deficiency of heterozygosity, indicated by positive $F_{\text {IS }}$ values, ranging from 0.037 to 0.171 .

\section{Phylogenetic relationship analysis}

The pairwise $F_{\mathrm{ST}}$ value and Nei's genetic distance across eight duck populations are shown in Table 3. The genetic distances were the shortest between RM and TR (0.021) and between BY and PG (0.051), while the least genetic relationship was between AL and PT (0.155) and between MJ and PT (0.367), based on $F_{\mathrm{ST}}$ value and Nei's genetic distances, respectively. The matrix of $F_{\mathrm{ST}}$ value and Neis genetic distances was further used to construct neighbor-joining (NJ) trees (Figure 2).

The resulted $\mathrm{NJ}$ trees revealed relatively similar results using both matrices. Two main clusters were formed, with AL, MJ, and MG duck populations in one cluster, whereas others joined together in a different cluster. Such clustering of the duck populations into two main clusters clearly indicated that some populations originated from different provinces and or islands. A PcoA is also presented using allele frequencies of 22 loci to summarize population relationships (Figure 3). The first, second and third components accounted for $54.20 \%$, $18.83 \%$, and $9.83 \%$, respectively to the total of genetic variability. AL and two populations (MG and MJ) were clearly separated into different single quadrate that differs from other populations (PcoA axis 1 and 2). In the PcoA axis 1 and 3, BY, PG, and RM formed one group that was near to TR, but still generally separated from AL, MJ, and MG populations.

\section{DISCUSSION}

\section{Genetic diversity analysis}

In this study, all microsatellite loci were found to be polymorphic. The average number of alleles in this study $(\mathrm{Na}=6.96)$ were lower than the findings of the other studies using same microsatellite markers in Asian duck populations, with number of alleles of 9.38 [12] and 11.5 [13]. Using three same loci (CAUD011, CAUD035, and CAUD066), nine to fiveteen alleles per locus were also observed by Liu et al [10] in Chinese indigenous duck breeds. Furthermore, five alleles were detected at APH24 locus in this study. Other genetic diversity indicators, however, showed values close to zero for Ho (0.026), He (0.079), and PIC (0.077). There was no detected alleles at $\mathrm{APH} 24$, as reported by Ismoyowati and Purwantini [14] in

Table 3. Pairwise population matrix of $F_{S T}$ values and Nei's genetic distances of eight duck populations

\begin{tabular}{lcccccccc}
\hline Population & AL & BY & MG & MJ & PG & PT & RM & TR \\
\hline AL & 0.000 & 0.295 & 0.133 & 0.196 & 0.270 & 0.298 & 0.271 & 0.335 \\
BY & 0.142 & 0.000 & 0.242 & 0.320 & 0.051 & 0.088 & 0.064 & 0.084 \\
MG & 0.076 & 0.086 & 0.000 & 0.093 & 0.262 & 0.290 & 0.176 & 0.210 \\
MJ & 0.099 & 0.120 & 0.038 & 0.000 & 0.307 & 0.367 & 0.226 & 0.274 \\
PG & 0.134 & 0.025 & 0.096 & 0.118 & 0.000 & 0.132 & 0.070 \\
PT & 0.155 & 0.045 & 0.109 & 0.142 & 0.067 & 0.000 & 0.116 \\
RM & 0.127 & 0.028 & 0.062 & 0.083 & 0.034 & 0.053 & 0.000 & 0.133 \\
TR & 0.149 & 0.033 & 0.073 & 0.100 & 0.040 & 0.061 & 0.051 \\
\hline
\end{tabular}

Above diagonal and below diagonal, $F_{\mathrm{ST}}$ values and Nei's genetic distances, respectively; AL, Alabio; BY, Bayang; MG, Magelang; MJ, Mojosari; PG, Pegagan; PT, Pitalah; RM, Rambon; TR, Turi. 

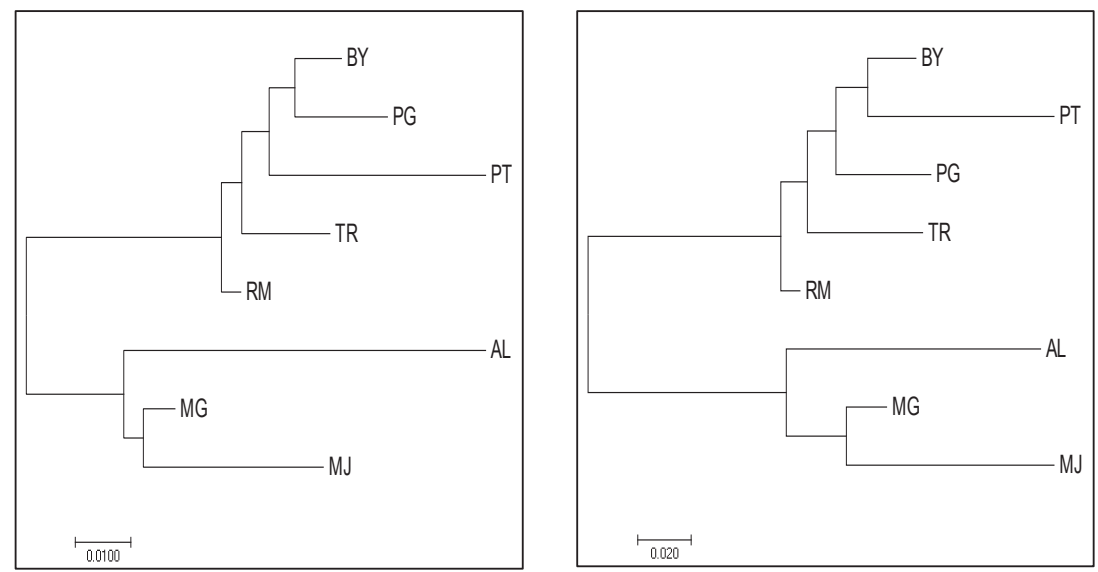

(A) A neighbor-joining tree based on $F_{\mathrm{ST}}$ values $\quad$ (B) A neighbor-joining tree based on Nei's genetic distances

Figure 2. Neighbor-joining tree constructed using pairwise population matrix of $F_{\mathrm{ST}}$ values (A) and Nei's genetic distances (B) of eight duck popullations. AL, Alabio; BY, Bayang; MG, Magelang; MJ, Mojosari; PG, Pegagan; PT, Pitalah; RM, Rambon; TR, Turi.

Indonesian duck populations (AL and Bali). The results suggest that genetic diversity of Indonesian local ducks is lower than other Asian duck populations.

To test the informativeness of observed loci, we measured PIC, with the resulting average value of 0.513 . For animal traceability, $\mathrm{PIC}>0.5$ and $\mathrm{He}>0.6$ are the most reasonable informative loci for application of genetics [20]. From 22 loci, twelve loci (PIC $>0.5$ ) were included as highly informative loci and were appropriate for assesing genetic diversity and population discrimination.

Based on the average value of expected heterozygosity (0.566), a moderate level of genetic diversity among populations stud-

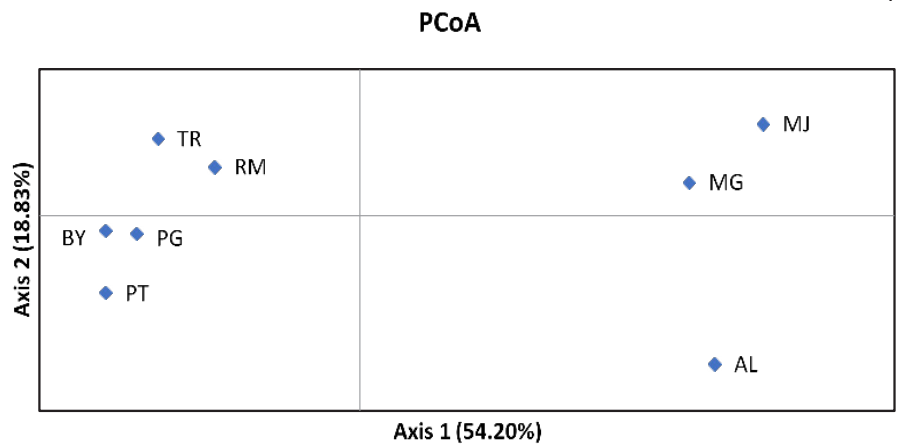

(A) Population relationships based on PcoA (axis 1 and 2)

PCoA

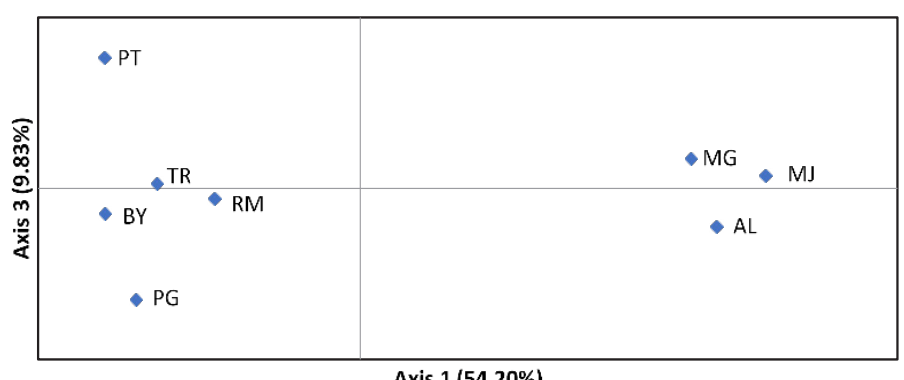

(B) Population relationships based on PcoA (axis 1 and 3)

Figure 3. Principal coordinates anaylsis (PcoA) of based on covariance matrix of Nei's genetic distance. (A) Population relationships based on PcoA (axis 1 and 2), (B) Population relationships based on PcoA (axis 1 and 3). AL, Alabio; BY, Bayang; MG, Magelang; MJ, Mojosari; PG, Pegagan; PT, Pitalah; RM, Rambon; TR, Turi. 
ied was obtained. In addition, heterozygote deficiency was detected, which was depicted by the lower average value of observed compared to expected heterozygosity, as well as the positive average value of $F_{\mathrm{IS}}$. Such phenomenon can be explained by various factors such as non-random mating, unamplified alleles ("null" alleles) and subdivision in populations studied (Wahlund's effects). The studied populations revealed a moderate genetic differentiation among eight populations $\left(F_{\mathrm{ST}}=0.137\right)$. The results showed that genetic diversity maintained within duck populations was higher than the one preserved among duck populations. This genetic diversity could be a valuable tool for implementing future genetic improvement and conservation of duck populations in Indonesia.

The genetic diversity indicators within eight duck populations are also summarized in Table 2. The mean number of alleles observed over a range of loci in different populations is considered to be a reasonable indicator of genetic variation within the populations [21]. The mean number of alleles was lowest (3.136) in the AL duck populations, as well as the values of Ho (0.371) and He (0.368). In contrast, RM and TR duck populations were highest for the mean number of alleles while MG duck population showed highest genetic diversity compared to the others $(\mathrm{He}=0.545)$. Observed heterozygosity was lower than expected heterozygosity in all populations, except AL duck population. This was also evidenced by positive values of $F_{\mathrm{IS}}$ in the seven populations, showing a departure from Hardy-Weinberg equilibrium. The disequilibrium was mainly caused by heterozygote deficiencies, as a result from the existence of inbreeding and or Wahlund effect (population substructure). Since the blood samples were collected from the same flock for each population, the existence of Wahlund effect may be ruled out. The reasonable cause of heterozygote deficiency is the presence of inbreeding. AL and MJ duck populations were reared under a intensive production system, established by livestock breeding center, while the remaining populations were reared under semi-intensive production systems by breeders in villages. Furthermore, after interviewing these breeders, it appears that often there is no pedigree record kept of the animals in semi-intensive production systems and mating between genetically related animals can occur. Unplanned and unsystematic breeding strategies may lead to the lack of sufficient number of breeding males in the breeding population. Mating between animals with similiar phenotypes also occured as the villagers believed mating between ducks with a certain feather colour produced offspring with higher egg production and thus, a panmixic population is unlikely to occur.

\section{Phylogenetic relationship analysis}

Genetic distance indicators of $F_{\mathrm{ST}}$ values and Nei's [22] genetic distances revealed a genetic relationship among eight duck populations. In general, relatively similar results were obtained from both indicators. Unsurprisingly, the greatest genetic distances were between MJ and PT and between AL and PT duck populations, based either $F_{\mathrm{ST}}$ values or Nei's genetic distance. PT duck population was sampled from a highland-isolated area, while the two AL and MJ duck populations were sampled from same livestock breeding center (BPTU-HPT Pelaihari) with a controlled breeding system. Projection of population relationships by constructing $\mathrm{NJ}$ trees based on the two indicators clearly separated the analyzed populations into two clusters. The clustering pattern was further supported by PcoA analysis. MG and MJ duck populations were consistently grouped in one cluster that was closer to the AL duck population compared to the remaining populations. One interesting result was that RM and TR duck populations (originated from Java island) also tended to join together and clustered with BY, PG, and PT duck populations (originated from Sumatera island) in both $\mathrm{NJ}$ trees. In the past, many migrants from Java island moved to Sumatera island and other larger islands in Indonesia to get more land for agriculture. Therefore, it is possible for BY, PG, PT, RM, and TR duck populations to share common ancestors when the migrants brought the ducks with them to the new region. The study highlighted that geograhic distance is not always a predictor of phylogenetic relationship. However, to get better understanding of phylogenetic among populations, it is important to combine information on the basis of phenotypic and molecular genetic characterization, as well as geographic and historical information of the analyzed populations.

In conclusion, the results of this study demonstrate moderate level of genetic diversity and differentiation among populations, but low to moderate level of genetic diversity within populations. Preventing loss of further alleles with low genetic diversity in populations studied should be considered by implementing effective breeding strategies to reduce inbreeding and increase heterozygosity. Also, the two major phylogenetic clusters clearly showed the genetic relationship of the duck populations. Finally, we highlighted the usefulness of these microsatellite markers to evaluate genetic diversity and phylogenetic relationship in local duck populations of Indonesia. The results indicate the risk status and threats to the duck populations and are useful for designing conservation plans and developing future genetic improvement.

\section{CONFLICT OF INTEREST}

We certify that there is no conflict of interest with any financial organization regarding the material discussed in the manuscript.

\section{ACKNOWLEDGMENTS}

This work represented an international research collaboration 
between Universitas Gadjah Mada, Yogyakarta, Indonesia and Chungnam National University, Daejeon, South Korea, supported by the Indonesian Ministry of research, Technology and Higher Education (RISTEKDIKTI) with contract No. 2262/UN1-P.III/DIT-LIT/LT/2017. We also thank the Agricultural and Livestock Bureau of Cirebon, Magelang, Ogan Ilir, Pesisir Selatan, Tanah Datar, and Livestock Breeding Center (BPTU-HPT) Pelaihari for assisting in the collection of blood samples from breeding flocks.

\section{REFERENCES}

1. FAO (Food and Agriculture Organization). Coping with climate change-the roles of genetic resources for food and agriculture. Rome, Italy: FAO; 2015.

2. Vaarst M, Steenfeldt S, Horsted K. Sustainable development perspectives of poultry production. Worlds Poult Sci J 2015;71: 609-20.

3. Li JY, Chen H, Lan XY, Kong XJ, Min LJ. Genetic diversity of five Chinese goat breeds assesed by microsatellite markers. Czech J Anim Sci 2008;53:315-9.

4. Simaei-Soltani L, Abdolmohammadi A, Zebarjadi A, Foroutanifar S. Genetic diversity and distance of Iranian goat breeds (Markhoz, Mahabadi and Lori) compared to the Beetal breed using inter-simple sequence repeat (ISSR) markers. Arch Anim Breed 2016;59:477-83.

5. Bao WB, Shu JT, Musa HH, Chen GH. Analysis of pairwise genetic distance and its relation with geographical distance of 15 Chinese chicken breeds. Int J Trop Med 2007;2:107-12.

6. Estoup A, Presa P, Krieg F, Vaiman D, Guyomard R. $(C T)_{n}$ and $(\mathrm{GT})_{\mathrm{n}}$ microsatellites: a new class of genetic markers for Salmo trutta L. (brown trout). Heredity 1993;71:488-96.

7. Moria BS, Permana GN, Hutapea JH. Characterization of three microsatellite loci of Yellow Fin tuna, Thunnus albacares eggs and larvae. J Fish Sci 2009;11:144-9.

8. Wright JM, Bentzen P. Microsatellites: genetic markers for the future. In: Carvalho GR, Pitcher TJ, editors. Molecular genetics in fisheries. Dordrecht, The Netherlands; Springer; 1995. p. 117-21.

9. Abdul Muneer PM, Gopalakrishnan A, Musammilu KK, et al. Comparative assessment of genetic variability in the populations of endemic and endangered Yellow Catfish, Horabagrus brachysoma (Teleostei: Horabagridae), based on allozyme, RAPD, and microsatellite markers. Biochem Genet 2012;50:192-212. 10. Liu W, Hou ZC, Qu LJ, et al. Population structure and biodiversity of Chinese indigenous duck breeds revealed by 15 microsatellite markers. Asian-Australas J Anim Sci 2008;21:314-9.

11. Gaur U, Tantia MS, Mishra B, et al. Population structuring of land and coastal ducks (Anas platyrhynchos) using microsatellite markers. Curr Sci 2016;110:1977-83.

12. Seo D, Bhuiyan MSA, Sultana H, Heo JM, Lee JH. Genetic diversity analysis of South and East Asian duck populations using highly polymorphic microsatellite markers. AsianAustralas J Anim Sci 2016;29:471-8.

13. Sultana H, Seo D, Choi NR, et al. Genetic diversity analysis of Asian duck populations using 24 microsatellite markers. Korean J Poult Sci 2017;44:75-81.

14. Ismoyowati, Purwantini D. Genetic variability of Bali and Alabio ducks on the basis of phenotypic and microsatellites. Asian J Poult Sci 2011;5:107-15.

15. Rusfidra, Heryandi Y, Jamsari, Rahman EY. Variasi genetik Itik Bayang berbasis marka mikrosatelit pada lokus AY287 dan lokus AY283. Sains Peternakan 2013;11:91-8.

16. Rahayu A, Purwantini D, Maharani, D, Hartatik T. Single nucleotide polymorphism identification and genotyping analysis of Melanocortin 1 receptor gene in various plumage colours in Magelang ducks. Int J Poult Sci 2015;14:207-12.

17. Marshall TC, Slate J, Kruuk LEB, Pemberton JM. Statistical confidence for likelihood-based paternity inference in natural populations. Mol Ecol 1998;7:639-55.

18. Peakall R, Smouse PE. GenAlEx 6.5: genetic analysis in Excel. Population genetic software for teaching and reasearch - an update. Bioinformatics 2012;28:2537-9.

19. Kumar S, Stecher G, Tamura K. MEGA7: Molecular evolutionary genetic analysis version 7.0 for bigger datasets. Mol Biol Evol 2016;33:1870-4.

20. Botstein D, White RL, Skolnik M, Davis RW. Construction of a genetic linkage map in man using restriction fragment length polymorphisms. Am J Hum Genet 1980;32:314-31.

21. MacHugh DE, Shriver MD, Loftus RT, Cunningham P, Bradley DG. Microsatellite DNA variation and the evolution, domestication and phylogeography of taurine and zebu cattle (Bos taurus and Bos indicus). Genetics 1997;146:1071-86.

22. Nei M. Genetic distances between population. Am Nat 1972; 106:283-92. 